\title{
The supplementary value of certain processed protein foods based on blends of groundnut, soya-bean, sesame, chick-pea (Cicer arietinum) flours and skim-milk powder to a maize-tapioca diet
}

\author{
By KANTHA JOSEPH, M. NARAYANARAO, M. SWAMINATHAN, \\ A. N. SANKARAN, A. PAUL JAYARAJ AND V. SUBRAHMANYAN \\ Central Food Technological Research Institute, Mysore, India
}

(Received ro April I96ז-Revised I9 Fune 196ז)

It is now generally recognized that the high incidence of kwashiorkor in children in India and certain other Asian countries, in Africa and in Latin America is the result of severe deficiency of protein in the diet (Trowell, Davies \& Dean, 1954; Autret \& Béhar, 1954; Gopalan \& Ramalingaswami, r955; Brock \& Autret, 1952). The diets consumed by children in these countries consist predominantly of cereals, roots and tubers; they contain only small amounts of legumes and negligible quantities of animal foods such as milk, fish, eggs and meat. The incidence of kwashiorkor is particularly high in regions where maize and tapioca are eaten (Trowell et al. 1954). In view of the scarcity of animal proteins, the possibility of using protein-rich foods of vegetable origin, such as legumes, oilseeds and oilseed meals, for the treatment and prevention of kwashiorkor has been investigated by some workers (Autret $\&$ van Veen, I955; Subrahmanyan, Bhagavan \& Swaminathan, I958; Scrimshaw, I959). The diets consumed by children suffering from kwashiorkor are deficient not only in proteins but also in other dietary essentials, such as vitamins and certain minerals including calcium and iron (Venkatachalam, Srikantiah \& Gopalan, 1954; Béhar, Arroyave, Flores \& Scrimshaw, I960; Flores, Flores \& Meneses, I957; Autret \& Béhar, 1954). Even though the primary objective in the treatment and prevention of kwashiorkor is to provide a supplementary source of protein, it is nevertheless desirable that the vegetable-protein mixtures should also be fortified with essential vitamins and minerals in which the poor dietaries are lacking. Since the quality of protein in the vegetable-protein foods is, in general, inferior to that of milk proteins, attempts should be made also to improve the quality of the proteins by blending suitably two or more vegetable proteins or by the addition of small amounts of skim-milk powder. This paper gives the results of studies of the effect of supplementing a maize-tapioca diet with certain processed protein foods (based on blends of groundnut, soya-bean, sesame and chick-pea (Cicer arietinum) flours and skim-milk powder) on the weight gain and the composition of blood, liver and carcass of albino rats. 


\section{EXPERIMENTAL}

Preparation of protein foods. Groundnut flour, chick-pea flour and sesame flour were prepared by the methods of Subrahmanyan, Ramarao, Kuppuswamy, Narayanarao \& Swaminathan (1957).

Soya-bean flour was prepared as follows. Soya-bean dhal (split beans, free from husk) was damped in water, and the excess water was drained off. The wet material was then left for $\mathrm{I} h$, so that adhering water was absorbed by the dhal. The material was steamed at ro $\mathrm{lb}$ pressure for $30 \mathrm{~min}$ to inactivate the tryptic inhibitor present, dried in a current of air at $45^{\circ}-50^{\circ}$ and powdered to pass through a 40 -mesh sieve.

Spray-dried skim-milk powder of good quality was used.

The protein foods were prepared by blending low-fat groundnut flour, soya-bean flour, sesame flour, chick-pea flour and skim-milk powder in different proportions as shown in Table I. The blends were fortified with thiamine, riboflavin, vitamins $A$ and $\mathrm{D}$ and calcium phosphate.

Table $\mathrm{x}$. Percentage composition of the different processed protein foods*

\begin{tabular}{lcccc}
\multicolumn{1}{c}{ Ingredient } & \multicolumn{4}{c}{ Protein food } \\
\cline { 2 - 4 } & A & B & C & D \\
Low-fat groundnut flour & 25 & 25 & 30 & - \\
Soya-bean flour & 30 & 30 & 30 & - \\
Sesame flour & - & 10 & 10 & - \\
Chick-pea flour (Cicer arietinum) & 25 & 25 & 30 & 80 \\
Skim-milk powder & 20 & 10 & - & 20
\end{tabular}

* The different foods were fortified with vitamins $A$ and $D$, thiamine, riboflavin and calcium phosphate (see Table 2).

Analytical methods. The proximate principles, minerals and vitamins in the protein foods were determined by the methods of the Association of Official Agricultural Chemists (1955). The results are given in Table 2.

The essential amino acid composition of the different oilseed meals, chick-pea flour and skim-milk powder used in the preparation of the protein foods was determined as shown below: methionine by the method of Horn, Jones \& Blum (1946), tryptophan by that of Spies (1950), histidine by that of Macpherson (1942) and other essential amino acids by the paper-chromatographic technique of Krishnamurthy \& Swaminathan (1955). The essential amino acid composition of the different processed protein foods was calculated from these results.

Protein efficiency ratio. The protein efficiency ratios (PER) of the proteins of the different blends were determined by the rat-growth method of Osborne, Mendel \& Ferry (I 19 ). Weanling male albino rats of the Wistar strain (28 days old, weighing 40-43 g) were allotted to different groups according to a simple randomized block design ignoring litters. The protein content of the diets was maintained at about 10\% on a dry-weight basis, the protein in each diet being derived from one of the protein foods. The diets were adequate in other nutrients. They were mixed with three times 
Table 2. Chemical composition of the different processed protein foods and the skim-milk powder

(Values per roo g)

$\quad$ Constitue
Moisture (g)
Protein (N×6.25)
Fat (g)
Ash (g)
Fibre (g)
Carbohydrate (by
Calcium (g)
Phosphorus (g)
Thiamine (mg)
Riboflavin (mg)
Vitamin A (i.u.) $)$
Vitamin D (i.u.) $\ddagger$

\begin{tabular}{|c|c|c|c|c|}
\hline \multicolumn{4}{|c|}{ Protein food* } & \multirow{2}{*}{$\begin{array}{c}\text { Skim- } \\
\text { milk } \\
\text { powder }\end{array}$} \\
\hline A & B & $\mathrm{C}$ & $\mathrm{D}$ & \\
\hline $\begin{array}{r}7 \cdot 9 \\
38 \cdot 7\end{array}$ & $\begin{array}{r}8.0 \\
38.9\end{array}$ & $\begin{array}{r}8.7 \\
38.8\end{array}$ & $\begin{array}{r}9 \cdot 8 \\
26.5\end{array}$ & $\begin{array}{r}4.1 \\
35 \cdot 6\end{array}$ \\
\hline $5 \cdot 6$ & 6.9 & $7 \cdot 6$ & 4.2 & $\begin{array}{r}530 \\
0.1\end{array}$ \\
\hline 4.7 & $4 \cdot 6$ & $4 \cdot 3$ & $3 \cdot 1$ & 6.8 \\
\hline$I \cdot 0$ & I.5 & $1 \cdot 5$ & 0.6 & - \\
\hline $42 \cdot I$ & 40.1 & $39 \cdot 1$ & $55 \cdot 8$ & $53 \cdot 4$ \\
\hline$I \cdot 30$ & $1 \cdot 32$ & $r \cdot 32$ & $1 \cdot 33$ & $I \cdot 34$ \\
\hline 0.99 & 0.95 & 0.89 & 0.92 & $I \cdot 00$ \\
\hline $2 \cdot 15$ & $2 \cdot 2 I$ & $2 \cdot 24$ & I.96 & $I \cdot 95$ \\
\hline $2 \cdot 55$ & $2 \cdot 39$ & $2 \cdot 25$ & $2 \cdot 52$ & $r \cdot 39$ \\
\hline 000 & 3000 & 3000 & 3000 & 3000 \\
\hline 300 & 300 & 300 & 300 & 300 \\
\hline
\end{tabular}

* See footnote to Table I.

+ Fortified with thiamine and vitamins $A$ and $D$.

† Value for added vitamin only.

their weight of water, cooked in steam for ro min and given ad lib to the rats. The rats were weighed weekly. The PERs were calculated for periods of 4 and 8 weeks.

Supplementary value to maize-tapioca diet. The supplementary value of the different protein foods when added at a $30 \%$ level to a maize-tapioca diet was determined by growth experiments on albino rats. No attempt was made to make the protein content of the diets equal. The compositions of the experimental diets are given in Table 3 .

Table 3. Percentage composition of the experimental diets

\begin{tabular}{|c|c|c|c|c|c|c|}
\hline \multirow[b]{2}{*}{ Ingredient } & \multicolumn{6}{|c|}{ Diet } \\
\hline & $\mathbf{I}$ & 2 & 3 & 4 & 5 & 6 \\
\hline Maize flour (100\% extraction) & $47 \cdot 0$ & $32 \cdot 0$ & $32 \cdot 0$ & $32 \cdot 0$ & $32 \cdot 0$ & $32 \cdot 0$ \\
\hline Tapioca flour & $47^{\circ} 0$ & $32 \cdot 0$ & $32 \cdot 0$ & $32 \cdot 0$ & $32 \cdot 0$ & $32 \cdot 0$ \\
\hline Groundnut oil & 5.0 & $5 \cdot 0$ & $5 \cdot 0$ & $5 \cdot 0$ & $5 \cdot 0$ & $5 \cdot 0$ \\
\hline Sodium chloride & $\mathbf{I} \cdot 0$ & $1 \cdot 0$ & $\mathbf{I} \cdot 0$ & $1 \cdot 0$ & $1 \cdot 0$ & $I \cdot O$ \\
\hline Protein food: A & - & $30 \cdot 0$ & 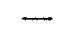 & - & - & - \\
\hline B & - & - & $30 \cdot 0$ & - & - & - \\
\hline $\mathrm{C}$ & 一 & - & - & $30 \cdot 0$ & - & - \\
\hline D & - & - & - & - & $30 \cdot 0$ & - \\
\hline Skim-milk powder & - & - & - & - & - & $30 \cdot 0$ \\
\hline
\end{tabular}

Groups of twelve freshly weaned albino rats, weighing about $40-45 \mathrm{~g}$ and distributed equally according to sex, litter and body-weight, were housed individually in raised wire-screen-bottom cages and fed ad lib. on the different diets. Another group of weanling rats weighing about $40 \mathrm{~g}$ was used to determine the initial body composition. The diets were mixed with three times their weight of water, cooked in steam for ro min and given to the rats. Records of daily food intake were kept for all the groups, and the rats were weighed weekly. After 8 weeks, the haemoglobin contents and red blood-cell counts were determined in blood drawn from the tails of 
the rats, haemoglobin by the acid haematin method with a Sahli-Hellige haemometer (Hepler, 1950) and red blood-cell counts by standard procedures with a Neubauer haemocytometer. The animals were then anaesthetized with amylobarbitone (Amytal) (Eli Lilly and Co. Ltd, Basingstoke, Hants). The rats were bled through the abdominal aorta to ensure minimum and uniform amounts of residual blood in the livers. The whole liver was quickly removed, washed with normal saline to remove adhering blood, wiped between filter-papers and immediately weighed in a glass dish. Samples of the liver were removed from the left lobe for histological examination. The moisture contents of the livers were determined by drying to constant weight at $90^{\circ}-95^{\circ}$ in an air oven. The dry liver samples were powdered, and measured portions were taken for the determination of total nitrogen and fat. Total nitrogen was determined by the micro-Kjeldahl method and fat by the method of Hawk \& Elvehjem (1953). The contents of the gastro-intestinal tract were removed by squeezing and the whole carcass was minced and weighed. Moisture, fat and protein contents of the carcass were determined by the same methods as for liver. As mentioned earlier, the protein content of the carcasses of a group (six males) of weanling rats ( 28 days old) weighing about $40 \mathrm{~g}$ in all was determined. From this result, the retention of protein in the different groups over a period of 8 weeks was calculated.

Histological examination of the livers. Samples of the liver taken from the left lobe were fixed in $10 \%$ formalin for histological examination. The tissues were processed through paraffin. Sections of $5 \mu$ thickness were taken and stained with haematoxylin and eosin. In addition, frozen sections were taken from each specimen and stained with Sudan IV in propylene glycol to study the distribution of fat.

\section{RESULTS}

Amino acid composition. Table 4 shows that the different protein foods contained less of all the essential amino acids (except arginine and histidine) than skim-milk powder; but judged by the FAO (1957) reference protein pattern, they were deficient only in tryptophan, methionine and cystine.

Table 4. Essential amino acid content $(\mathrm{g} / \mathrm{1} 6 \mathrm{~g} \mathrm{~N})$ of the processed protein foods and of the skim-milk powder*

\begin{tabular}{|c|c|c|c|c|c|c|}
\hline \multirow[b]{2}{*}{ Amino acid } & \multicolumn{4}{|c|}{ Protein food } & \multirow{2}{*}{$\begin{array}{l}\text { Skim- } \\
\text { milk } \\
\text { powder }\end{array}$} & \multirow{2}{*}{$\begin{array}{c}\text { FAO (I957) } \\
\text { reference } \\
\text { protein } \\
\text { pattern }\end{array}$} \\
\hline & A & B & C & D & & \\
\hline Arginine & $8 \cdot 0$ & $8 \cdot 4$ & $9 \cdot 0$ & 6.2 & $4 \cdot 3$ & - \\
\hline Histidine & 2.5 & 2.5 & $2 \cdot 4$ & $2 \cdot 4$ & $2 \cdot 4$ & - \\
\hline Lysine & $5 \cdot 9$ & $5 \cdot 3$ & $5 \cdot 5$ & $7 \cdot 0$ & $8 \cdot 5$ & $4 \cdot 2$ \\
\hline Tryptophan & $1 \cdot 2$ & $1 \cdot 2$ & $1 \cdot 2$ & 0.8 & $1 \cdot 6$ & $\mathrm{I} \cdot 4$ \\
\hline Phenylalanine & $5 \cdot 3$ & $5 \cdot 5$ & $5 \cdot 5$ & $5 \cdot I$ & $5 \cdot 6$ & $2 \cdot 8$ \\
\hline Methionine & 1.6 & $1 \cdot 7\}_{3 \cdot x}$ & & $2 \cdot I\}$ & $3 \cdot 2\}_{4 \cdot 3}$ & $2.2\}_{4.2}$ \\
\hline Cystine & $\mathrm{I} \cdot 4\} 3.0$ & $I \cdot 4\} 3 \cdot I$ & $1.4\}^{2.9}$ & $0.9\}$ & $I \cdot I\} 4 \cdot 3$ & $2 \cdot 0\} 4.2$ \\
\hline Threonine & $3 \cdot 4$ & $3 \cdot 4$ & $3 \cdot 2$ & $4 \cdot 5$ & $4 \cdot 8$ & $2 \cdot 8$ \\
\hline Leucine & $8 \cdot \mathrm{I}$ & $7 \cdot 7$ & $7 \cdot 5$ & $8 \cdot 7$ & II 2 & $4 \cdot 8$ \\
\hline Isoleucine & $5 \cdot 8$ & $5 \cdot 6$ & 5.4 & $6 \cdot 4$ & $7 \cdot 7$ & $4 \cdot 2$ \\
\hline Valine & $5 \cdot 3$ & $5 \cdot 2$ & 5.0 & $5 \cdot 8$ & $7 \cdot 2$ & $4 \cdot 2$ \\
\hline
\end{tabular}


Protein efficiency ratio. The results given in Table 5 show that the protein efficiency ratios of the protein foods ranged from $2 \cdot 25$ to $2 \cdot 36$ in the 4 -week test and from $\mathrm{I} \cdot 8 \mathrm{I}$ to I.84 in the 8 -week test. These values were significantly $(P<0.001)$ less than those for the proteins of skim-milk powder $(2.98$ in the 4 -week and $2 \cdot 19$ in the 8 -week test, respectively), but higher than the values reported in the literature for the proteins of groundnut and chick-pea and almost equal to that for soya-bean proteins (Kuppuswamy, Srinivasan \& Subrahmanyan, 1958).

Table 5. Protein efficiency ratios of the proteins of the protein foods and skim-milk powder determined with groups of eight young rats at a $10 \%$ level of protein intake (means and their standard errors)

\begin{tabular}{|c|c|c|c|}
\hline \multirow[b]{2}{*}{ Protein food } & \multicolumn{3}{|c|}{ Protein efficiency ratio } \\
\hline & 4-week period & 8-week & period \\
\hline $\mathbf{A}$ & $2 \cdot 3^{6}$ & $I \cdot 82$ & \\
\hline D & $\begin{array}{l} \pm 0.08 \\
(28 \mathrm{df})\end{array}$ & $\begin{array}{l}\mathrm{I} \cdot 84 \\
\mathrm{I} \cdot 82\end{array}$ & $\begin{array}{l} \pm 0.05 \\
(28 \mathrm{df})\end{array}$ \\
\hline Skim-milk powder & $\begin{array}{l}2 \cdot 34 \\
2 \cdot 98\end{array}$ & $\begin{array}{l}I \cdot 81 \\
2 \cdot 19\end{array}$ & \\
\hline
\end{tabular}

Weight gain and composition of blood. The results given in Table 6 show that the different protein foods, when incorporated at a $30 \%$ level in a maize-tapioca diet, produced a highly significant $(P<0.00 \mathrm{I})$ increase in the weight of the rats. There was no significant difference in rate of weight gain between rats receiving the different protein foods or skim-milk powder. The red blood-cell count and the haemoglobin content of the blood of the rats receiving the protein supplements or skim-milk powder were significantly higher than those of the rats on the control maize-tapioca $\operatorname{diet}($ Table 6).

Table 6. Effect of supplementing the maize-tapioca diet during 8 weeks with the different protein foods on the weight gains and on composition of the blood of rats

\begin{tabular}{|c|c|c|c|c|c|c|c|c|c|}
\hline $\begin{array}{c}\text { Supplement } \\
\text { to } \\
\text { diet* }\end{array}$ & $\begin{array}{c}\text { Protein } \\
\text { content } \\
\text { of diet (on } \\
\text { moisture- } \\
\text { free basis) } \\
(\%)\end{array}$ & $\begin{array}{l}\text { Initial } \\
\text { body- } \\
\text { weight } \\
\text { (g) }\end{array}$ & $\begin{array}{c}\text { Daily food } \\
\text { intake (on } \\
\text { moisture- } \\
\text { free } \\
\text { basis) } \\
\text { (g) }\end{array}$ & $\begin{array}{l}\text { W } \\
\text { ga } \\
\text { we }\end{array}$ & $\begin{array}{l}\text { ekly } \\
\text { n in } \\
\text { ght } \uparrow \\
\text { g) }\end{array}$ & $\begin{array}{r}\text { Haems } \\
(\mathrm{g} / \mathrm{I} \\
\mathrm{blc}\end{array}$ & $\begin{array}{l}\text { globin } \neq \\
\text { o ml } \\
\text { od) }\end{array}$ & $\begin{array}{r}\mathrm{Re} \\
\mathrm{co} \\
(10- \\
\mathrm{b}\end{array}$ & $\begin{array}{l}\text { d cell } \\
\text { untf } \\
6 / \mathrm{mm}^{3} \\
\text { lood) }\end{array}$ \\
\hline None & $6 \cdot 50$ & $4^{6 \cdot 7}$ & $8 \cdot 7$ & 4.21 & & $13 \cdot 10$ & & $7^{*} 15$ & \\
\hline Protein food: A & $17 \cdot 16$ & $46 \cdot 8$ & II 9 & $14 \cdot 20$ & & 14.90 & & $8 \cdot 95$ & \\
\hline B & $17 \cdot 24$ & $47 \cdot 0$ & $12 \cdot 0$ & 14.23 & \pm 0.591 & $15 \cdot 22$ & \pm 0.179 & 9.02 & \pm 0.138 \\
\hline $\mathrm{C}$ & $17 \cdot 20$ & $47 \cdot 0$ & II $\cdot 6$ & 14.94 & (5० df) & I $5 \cdot 37$ & $(25 \mathrm{df})$ & 9.09 & $(25 \mathrm{df})$ \\
\hline & 13.21 & $47 \cdot I$ & II 17 & 13.45 & & $15 \cdot 19$ & & $9^{\circ} 02$ & \\
\hline $\begin{array}{l}\text { Skim-milk } \\
\text { powder }\end{array}$ & $16 \cdot 17$ & $46 \cdot 9$ & $12 \cdot 1$ & 15.57 & & $15 \cdot 18$ & & 9.24 & \\
\hline \multirow{3}{*}{\multicolumn{4}{|c|}{$\begin{aligned} \text { Critical difference at: } & 5 \% \text { level } \\
& 1 \% \text { level } \\
& 0.1 \% \text { level }\end{aligned}$}} & $\mathrm{I} \cdot 68$ & & 0.52 & & 0.40 & \\
\hline & & & & $2 \cdot 24$ & & 0.71 & & 0.54 & \\
\hline & & & & 2.93 & & 0.94 & & 0.73 & \\
\hline
\end{tabular}

* Replaced an equal weight of tapioca and maize.

+ Mean values with their standard error for six male and six female rats per group.

I Mean values with their standard error for six male rats only. 


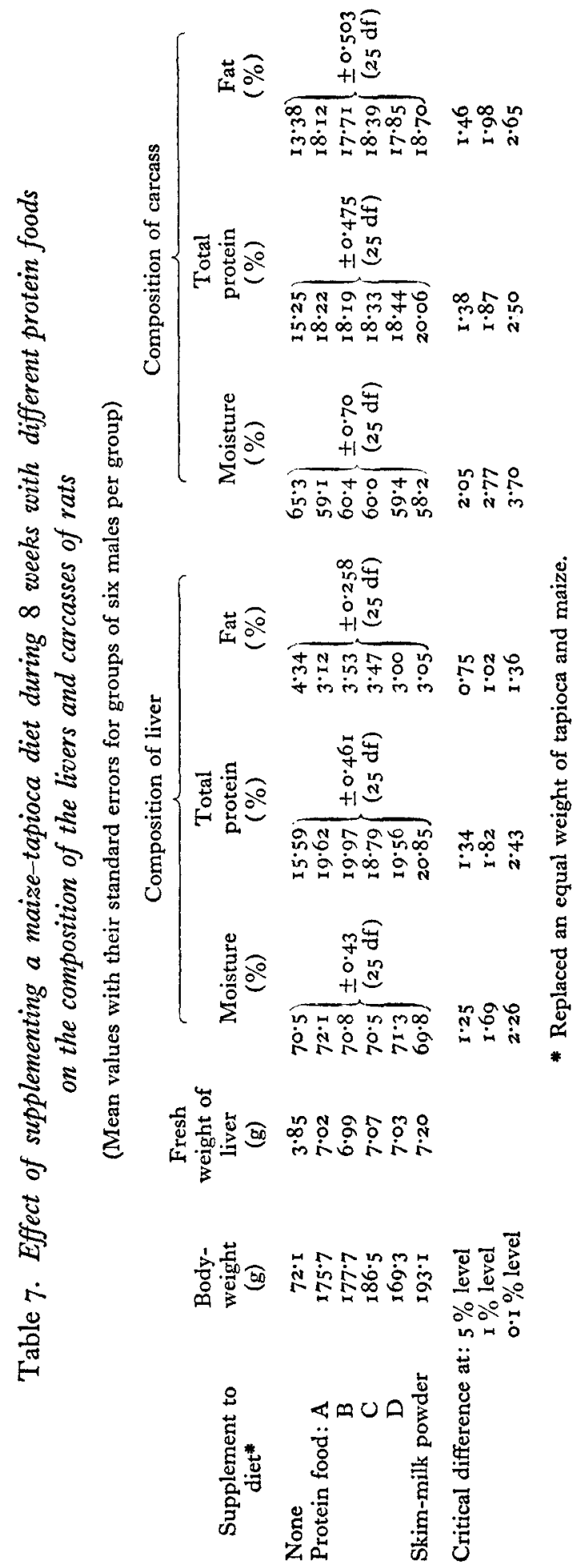


Composition of liver and carcass. Table 7 shows the results of the analysis of the livers and carcasses of the rats fed on the different diets. There was no significant difference in the mean fat and protein contents of the livers and carcasses of the rats receiving the different protein foods or the skim-milk powder. The mean fat content of the livers of the rats fed on the control maize-tapioca diet was significantly higher $(P<0.0 \mathrm{I})$ and the protein content significantly lower $(P<0.00 \mathrm{I})$ than the corresponding values for the rats that received the different protein supplements or skim-milk powder. The mean protein content of the carcasses of the rats fed on the maize-tapioca diet was also significantly lower $(P<0.001)$ than in the other groups.

Histological structure of livers. Livers of animals on the maize-tapioca diet showed a mild to moderate degree of parenchymal damage of the protein-deficiency type. The liver cells showed reduction in cytoplasmic protein. Varying degrees of cytoplasmic vacuolation of the protein-deficiency type were observed. The parenchymal damage was localized round the portal areas. Frozen sections stained with Sudan IV showed abundant stainable fat deposited round the periportal areas. Fatty infiltration was not seen round the central vein. Necrosis of the liver cells was absent. The liver sections of rats receiving the protein supplements or skim-milk powder were normal, indicating that the different protein foods were as effective as skim-milk powder in correcting the deficiencies of protein and other dietary essentials in the diet and in preventing liver damage.

Table 8. Intake and retention of protein by the rats during 8 weeks

\begin{tabular}{|c|c|c|c|c|c|c|}
\hline \multirow{3}{*}{$\begin{array}{l}\text { Supplement } \\
\text { to diet* }\end{array}$} & \multirow{3}{*}{$\begin{array}{l}\text { Total } \\
\text { protein } \\
\text { intake } \\
(\mathrm{g})\end{array}$} & \multirow{3}{*}{$\begin{array}{c}\text { Total } \\
\text { increase in } \\
\text { body-weight } \\
\text { (g) }\end{array}$} & & & \multicolumn{2}{|c|}{ Protein retained } \\
\hline & & & \multicolumn{2}{|c|}{ Body protein $(\mathrm{g})$} & \multirow[b]{2}{*}{ g } & \multirow{2}{*}{$\begin{array}{c}\mathrm{g} / \mathrm{r} 00 \mathrm{~g} \\
\text { increase in } \\
\text { body-weight }\end{array}$} \\
\hline & & & Initial $\uparrow$ & Final & & \\
\hline None & $3 I .9$ & $25 \cdot 8$ & $8 \cdot 15$ & ro.99 & $2 \cdot 84$ & 10.99 \\
\hline Protein food: A & I I $4: 0$ & $129 \cdot 4$ & $8 \cdot 15$ & $32 \cdot 01$ & $23 \cdot 86$ & $18 \cdot 44$ \\
\hline B & 115.8 & 131.0 & $8 \cdot 22$ & $32 \cdot 32$ & $24 \cdot 10$ & I $8 \cdot 40$ \\
\hline $\mathrm{C}$ & 1 I $1 \cdot 8$ & 139.5 & $8 \cdot 27$ & $34 \cdot 19$ & 25.92 & $18 \cdot 58$ \\
\hline $\bar{D}$ & $86 \cdot 8$ & $122 \cdot 3$ & $8 \cdot 27$ & $3 I \cdot 22$ & $22 \cdot 95$ & 18.77 \\
\hline Skim-milk powder & $109 \cdot 7$ & $146 \cdot 6$ & $8 \cdot 19$ & $3^{8 \cdot 74}$ & 30.55 & $20 \cdot 84$ \\
\hline
\end{tabular}

Intake and retention of proteins. Table 8 shows the intakes and retentions of protein by the rats fed on different diets. No significant difference was observed in the amount of protein retained per $100 \mathrm{~g}$ increase in body-weight of rats receiving the different protein supplements or skim-milk powder. On the other hand, the amount of protein retained per $100 \mathrm{~g}$ increase in body-weight on the maize-tapioca diet was significantly lower than that observed in the groups receiving the protein supplements.

\section{DISCUSSION}

The results show that processed protein foods based on blends of low-fat groundnut flour, soya-bean flour, chick-pea flour, sesame flour and skim-milk powder, and fortified with calcium, vitamins $A$ and $D$, thiamine and riboflavin. contain proteins 
of fairly high nutritive value. When incorporated at a $30 \%$ level in a maize-tapioca diet, they could meet as effectively as an equivalent amount of skim-milk powder the protein requirements of young rats. The livers of rats receiving the different protein supplements had a normal histological appearance, whereas the livers of rats fed on the control maize-tapioca diet showed periportal fatty infiltration and cytoplasmic vacuolation. It may be of interest to note that one of the protein blends (blend D, containing 80 parts of chick-pea and 20 parts of skim-milk powder) used in this study has been reported to be effective in the treatment of kwashiorkor in children (Venkatachalam, 1956).

Blends of low-fat groundnut flour, chick-pea flour and skim-milk powder have also been reported effective in the treatment of kwashiorkor (Subrahmanyan, Doraiswamy, Joseph, Narayanarao \& Swaminathan, I957; Bharucha \& Edibam, 1960; Purushowtham Rao, 1960). It may be concluded from our results and from those reported in earlier studies (Subrahmanyan, Doraiswamy et al. 1957; Subrahmanyan, Doraiswamy, Bhagavan, Narayanarao, Sankaran \& Swaminathan, 1959) that processed protein foods based on low-fat groundnut flour, soya-bean flour, chick-pea flour and skim-milk powder and fortified with calcium and certain essential vitamins could safely be used as protein supplements for the prevention and treatment of kwashiorkor in children in underdeveloped countries.

\section{SUMMARY}

I. The supplementary value for a maize-tapioca diet of four processed protein foods was studied by growth experiments on albino rats. The foods were blends of two or more of the following: low-fat groundnut flour, soya-bean flour, sesame flour, chick-pea flour and skim-milk powder. They were fortified with vitamins A and D, thiamine and riboflavin and calcium phosphate.

2. When incorporated in the diet at a $30 \%$ level (providing about $7-11 \%$ extra protein) the different protein foods were as effective as an equivalent amount of skimmilk powder in promoting the gain in weight of rats. No significant differences were observed in the mean protein content of the carcasses or livers of rats receiving the protein foods or skim-milk powder.

3. The protein efficiency ratios of the proteins of the different blends (at a 10\% level of protein intake) determined on groups of eight male rats, ranged from $2 \cdot 25$ to $2 \cdot 36$ in a 4 -week test and from $\mathrm{r} \cdot 8 \mathrm{r}$ to $\mathrm{r} \cdot 84$ in an 8 -week test as compared with values of $2 \cdot 98$ and $2 \cdot 19$ respectively for skim-milk powder.

4. The livers of animals receiving the maize-tapioca diet showed a moderate degree of parenchymal damage of the protein-deficiency type and severe periportal fatty infiltration. On the other hand, the livers of animals receiving the different protein foods or skim-milk powder were normal, indicating thereby that the different protein foods were as effective as skim-milk powder in correcting the protein deficiency in the diet and in preventing liver damage.

Our thanks are due to Miss K. Indiramma for help in the statistical analysis of results. 


\section{REFERENCES}

Association of Official Agricultural Chemists (1955). Official Methods of Analysis, 8th ed. Washington: Association of Official Agricultural Chemists.

Autret, M. \& Béhar, M. (r954). F.A.O. nutr. Stud. no. 13.

Autret, M. \& van Veen, A. G. (1955). Amer. F. clin. Nutr. 3, 234.

Béhar, M., Arroyave, G., Flores, M. \& Scrimshaw, N. S. (1960). Brit. F. Nutr. 14, 217.

Bharucha, E. P. \& Edibam, B. C. (r960). Indian F. Child Hlth, 9, $26 \mathrm{r}$.

Brock, J. F. \& Autret, M. (1952). F.A.O. nutr. Stud. no. 8.

FAO (1957). F.A.O. nutr. Stud. no. 16.

Flores, M., Flores, Z. \& Meneses, B. (1957). Arch. venez. Nutr. 8, 57.

Gopalan, C. \& Ramalingaswami, V. (1955). Indian Y. med. Res. 43, 75r.

Hawk, E. A. \& Elvehjem, C. A. (1953). F. Nutr. 49, 495.

Hepler, O. E. (1950). Manual of Clinical Laboratory Methods, 7 th ed. Springfield, Ill.: C. C. Thomas.

Horn, M. J., Jones, D. B. \& Blum, A. E. (1946). F. biol. Chem. 166, 313.

Krishnamurthy, K. \& Swaminathan, M. (1955). Analyt. Chem. 27, 1936.

Kuppuswamy, S., Srinivasan, M. \& Subrahmanyan, V. (1958). Proteins in Foods. New Delhi: Indian Council of Medical Research.

Macpherson, H. T. (1942). Biochem. 7. 36, 59.

Osborne, T. B., Mendel, L. B. \& Ferry, E. L. (1919). F. biol. Chem. 37, 223.

Purushowtham Rao, G. (1960). Indian F. Child Hlth, 9, 207.

Scrimshaw, N. S. (1959). F. Amer. diet. Ass. 35, 44I.

Spies, J. R. (1950). Analyt. Chem. 22, I447.

Subrahmanyan, V., Bhagavan, R. K. \& Swaminathan, M. (1958). Indian F. Pediat. $25,216$.

Subrahmanyan, V., Doraiswamy, T. R., Bhagavan, R. K., Narayanarao, M., Sankaran, A. N. \& Swaminathan, M. (1959). Indian F. Pediat. 26, 406.

Subrahmanyan, V., Doraiswamy, T. R., Joseph, K., Narayanarao, M. \& Swaminathan, M. (1957). Indian $\mathcal{F}$. Pediat. 24, I 12.

Subrahmanyan, V., Ramarao, G., Kuppuswamy, S., Narayanarao, M. \& Swaminathan, M. (1957). Food Sci. 6, 76 .

Trowell, H. C., Davies, J. N. P. \& Dean, R. F. A. (1954). Kwashiorkor. London: Edward Arnold (Publishers) Ltd.

Venkatachalam, P. S. (1956). Rep. nutr. Res. Lab., Hyderabad.

Venkatachalam, P. S., Srikantiah, S. G. \& Gopalan, C. (1954). Indian F. med. Res. 42, 555. 